2014s-27

\title{
Post-Investment Migration of Canadian Venture Capital-Backed New Technology-Based Firms
}

Cécile Carpentier, Jean Marc Suret

\begin{tabular}{c}
\hline Série Scientifique \\
Scientific Series
\end{tabular}

Montréal

Avril 2014

(C) 2014 Cécile Carpentier, Jean Marc Suret s. Tous droits réservés. All rights reserved. Reproduction partielle permise avec citation du document source, incluant la notice $($ ).

Short sections may be quoted without explicit permission, if full credit, including (C) notice, is given to the source.
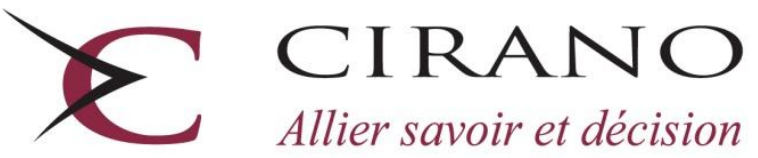

Allier savoir et décision

Centre interuniversitaire de recherche en analyse des organisations 


\section{CIRANO}

Le CIRANO est un organisme sans but lucratif constitué en vertu de la Loi des compagnies du Québec. Le financement de son infrastructure et de ses activités de recherche provient des cotisations de ses organisations-membres, d'une subvention d'infrastructure du Ministère de l'Enseignement supérieur, de la Recherche, de la Science et de la Technologie, de même que des subventions et mandats obtenus par ses équipes de recherche.

CIRANO is a private non-profit organization incorporated under the Québec Companies Act. Its infrastructure and research activities are funded through fees paid by member organizations, an infrastructure grant from the Ministère de l'Enseignement supérieur, de la Recherche, de la Science et de la Technologie, and grants and research mandates obtained by its research teams.

\section{Les partenaires du CIRANO}

\section{Partenaire majeur}

Ministère de l'Enseignement supérieur, de la Recherche, de la Science et de la Technologie

\section{Partenaires corporatifs}

Autorité des marchés financiers

Banque de développement du Canada

Banque du Canada

Banque Laurentienne du Canada

Banque Nationale du Canada

Banque Scotia

Bell Canada

BMO Groupe financier

Caisse de dépôt et placement du Québec

Fédération des caisses Desjardins du Québec

Financière Sun Life, Québec

Gaz Métro

Hydro-Québec

Industrie Canada

Intact

Investissements PSP

Ministère des Finances et de l'Économie

Power Corporation du Canada

Rio Tinto Alcan

Transat A.T.

Ville de Montréal

\section{Partenaires universitaires}

École Polytechnique de Montréal

École de technologie supérieure (ÉTS)

HEC Montréal

Institut national de la recherche scientifique (INRS)

McGill University

Université Concordia

Université de Montréal

Université de Sherbrooke

Université du Québec

Université du Québec à Montréal

Université Laval

Le CIRANO collabore avec de nombreux centres et chaires de recherche universitaires dont on peut consulter la liste sur son site web.

Les cahiers de la série scientifique (CS) visent à rendre accessibles des résultats de recherche effectuée au CIRANO afin de susciter échanges et commentaires. Ces cahiers sont écrits dans le style des publications scientifiques. Les idées et les opinions émises sont sous l'unique responsabilité des auteurs et ne représentent pas nécessairement les positions du CIRANO ou de ses partenaires.

This paper presents research carried out at CIRANO and aims at encouraging discussion and comment. The observations and viewpoints expressed are the sole responsibility of the authors. They do not necessarily represent positions of CIRANO or its partners. 


\title{
Post-Investment Migration of Canadian Venture Capital- Backed New Technology-Based Firms*
}

\author{
Cécile Carpentier ${ }^{\dagger}$, Jean Marc Suret ${ }^{*}$
}

\begin{abstract}
Résumé/abstract
Numerous innovative Canadian new technology-based firms migrate abroad when local venture capitalists exit. This article aims to determine how common this type of exit is, and to understand the motivations behind and the consequences of these migrations. We use a mixed-methodology approach, combining quantitative and qualitative evidence. At the market level, we find that nearly half of successful venture capital exits from Canadian firms result in migration. Using a pattern matching approach with 14 cases, we show that these migrations are motivated mainly by strategic considerations in the context of a small country with few strategic partners and a small market for innovative products. Acquired firms become truncated companies with declining activities. Only a small proportion of bought-out entrepreneurs reinvest in the local economy. This phenomenon probably has strong negative effects on the creation of new large technological firms and clusters.
\end{abstract}

Mots clés/Keywords : Migration, venture capital, exit, trade sale.

Codes JEL : L26, M13, G24, G28

\footnotetext{
* The authors thank Nicolas Ros and Keven Bluteau for valuable research assistance. This research was supported by the Fonds pour l'éducation et la saine gouvernance of the Autorité des marchés financiers du Québec (the 'Autorité'). The comments and opinions expressed by the authors of this article do not necessarily reflect the opinion of the Autorité.

${ }^{\dagger}$ Corresponding author: School of Accountancy, Faculty of Administrative Science, Laval University, 6226 Pavilion Palasis-Prince, G1V 0A6, Québec, Canada, Phone: (418) 656 7134, Fax: (418) 6567746. Email: jean-marc.suret@fsa.ulaval.ca. Jean-Marc Suret is professor at Laval University, Québec, Canada, CIRANO Fellow and associate member of the European Center for Corporate Control Studies. He specializes in corporate finance, public policy and regulation.

¥ Cécile Carpentier is professor at Laval University, Québec, Canada, CIRANO Fellow and associate member of the European Center for Corporate Control Studies. Her research interests include small business finance and corporate finance. Email: cecile.carpentier@fsa.ulaval.ca.
} 


\section{Introduction}

Worldwide, an increasing number of new technology-based firms (NTBF) are acquired by foreign firms, including Google, Apple, Yahoo!, Facebook and Microsoft. These NTBF often migrate toward other countries (Teubal and Avnimelech, 2003; Scott-Kennel, 2013). Consequently, domestic appropriation of the benefits of knowledge investments is becoming a central question (Freeman and Soete, 2009, p.588). This problem is crucial for small economies like Israel (Rosenberg, 2002; Teubal and Avnimelech, 2003), New Zealand (Davenport, 2009; Enderwick and Scott-Kennel, 2009), several European countries including Sweden (Dahlstrand, 2000), Latin American emerging markets (Gonzalo et al., 2013) and even the US (Reynolds et al., 2014). Venture capital (VC) internationalisation is prompting NTBF migration because crossborder VC investment augments the set of exit opportunities and eases the migration of NTBF toward foreign locations (Mäkelä and Maula, 2005, 2008; Bertoni and Groh, 2014). According to Narula and Zanfei (2005 p.339), internationalisation of R\&D may lead to a "hollowing out" of the home country's innovatory capacity, but there is currently little evidence supporting this hypothesis, which is an important area for future research. Mäkelä and Maula (2005) conclude that foreign investors tend to drive portfolio companies toward their home market, inducing potentially negative effects.

Cross-border VC investments are not the sole source of NTBF migrations. They also result from the increasing propensity of venture capitalists (VCs) to exit through trade sales (Ritter et al., 2013) and from the appetite of large technology-based firms for young innovative companies (Bena and Li, 2013). This article examines migrations induced by local VCs. The phenomenon is particularly important in small open economies like Canada, a country that invests heavily in the national innovation system but exhibits very poor performance in innovation and productivity 
gains (Doyle et al., 2004). Canada is among the top 3 countries in spending per capita on public postsecondary education (Organisation for Economic Co-operation \& Development, OECD, 2012 p.209) and has the highest proportion of workers who have completed post-secondary education (Expert Panel, 2009). The Canadian Scientific Research \& Experimental Development program ranks third among OECD countries. Canada ranks second in entrepreneurship rate (or total early stage activity) out of 24 countries (Langford et al., 2014) and has one of the highest levels of VC investment as a share of GDP among OECD countries (Baygan, 2003). Groh et al. (2012) rank Canada third in terms of VC and private equity country attractiveness out of 80 countries. Despite these potentially favourable conditions, Canada lags behind most OECD countries in terms of innovation and productivity, ranking $13^{\text {th }}$ among 16 peer countries. ${ }^{1}$ The country's lagging productivity growth is largely due to weak business innovation (Expert Panel, 2009). Fagerberg and Srholec (2008 appendix 2) give the Canadian innovation system a score similar to that of Greece for 2000-2004; only one of 22 developed countries has a lower score. Canadian underperformance in innovation has not been clearly explained, but the Expert Panel (2009 p.102) suggests that “Canada's failure to develop a greater number of innovative Canadian-based multinationals has been a key contributor to the country's overall R\&D weakness.” Few large high-tech companies are based in this country. Moreover, "High-tech names have been vanishing from the radar in Canada at an alarming rate. (...) Worse, most of those companies are selling out too early, before they have a chance to grow into larger, global businesses that could fuel further innovation and success in the tech sector.”2 Several journal articles have mentioned the Canadian "hollowing out" spectra. ${ }^{3}$ If the most promising VC-backed NTBFs migrate, this can partially explain the observation of the Expert Panel and justifies the present research. 
Firm migration is an important research topic, largely ignored by scholars (Mason and Harrison, 2006; Anokhin, 2013). Knowledge of the reasons, extent and economic impact of the acquisition of locally-owned NTBFs by remote large firms is limited, and the economic effects of such migrations seem to depend on the characteristics and circumstances of the transaction (Dahlstrand, 2000; Mason and Harrison, 2006; Foreman-Peck and Nicholls, 2013). Several affirmations and explanations emerge from the various reports and academic works, but sparse data exist to ground these statements. We analyse the extent, reasons and consequences of foreign exits among Canadian NTBFs mainly financed by Canadian VCs. The main research questions fit the research agenda provided by Mason and Harrison (2006 p.68) who suggest that there is a need to 1) determine how common it is for VC to drive this type of harvest process; 2) understand the circumstances leading to the decision to sell; and 3) look at local post-acquisition effects. To answer such questions we quantitatively assess the extent of the phenomenon and qualitatively analyse the motivations and consequences. Accordingly, we use a mixed approach, as suggested by Molina-Azorin et al. (2011). We combine quantitative data describing Canadian VC exits at the market level and a pattern-matching approach based on qualitative data from 14 cases of migration. Our results show that:

1) Foreign trade sales (FTS) are very common and increasing in Canada.

2) Such transactions are best explained by strategic considerations and occur between complementary firms.

3) FTS result in a clear crowding-out effect and there is limited evidence of financial recycling.

The remainder of this article is structured as follows. Part one presents the methodology. Part two summarises the literature, and states our propositions and expected patterns. We discuss the data 
in Part three and our results in Part four. The article ends with discussions and implications for public policy.

\section{Methodology}

Firm migrations and the effect of foreign VCs on exits have been investigated using case studies and quantitative methods (Mäkelä and Maula, 2005; Mason and Harrison, 2006). Experts have written reports to explain the Canadian paradox and the problem of the commercialisation of innovation in this country. Although several propositions have been put forth regarding the motivations and consequences of migrations, this phenomenon has not been quantified precisely. Hence our methodological choices.

First, we decided on a mixed-methods approach. Quantitative data is used to determine the extent of the FTS phenomenon and to situate selected cases in the group of VC-backed companies. According to Molina-Azorin et al. (2011), the mixed approach is well suited to analysis of the outcome and process in the same study, and to capture several facets of a phenomenon. Second, the qualitative part of our study uses the pattern matching approach for rival explanations (Dul and Hak, 2008; Yin, 2014). This method facilitates comparison of empirically based patterns emerging from the qualitative data with predicted patterns. Specifically, we perform visual inspection of patterns to determine whether they match or not (Dul and Hak, 2008). This approach is considered as one of the most desirable for case study analysis (Yin, 2014 p.143). It is particularly well suited to attempts to test the propositions with the data gathered (Hyde, 2000; Bitektine, 2008; Yin, 2014). Starting from competing propositions based on previous research and theory, we specified an expected pattern composed of independent outcomes that are predicted to occur according to each of the propositions. Multiple cases let us determine how well each case fits the explanations or assertions. This "deductive” logic approach (Yin, 2014) has 
been used by Taylor and Jack (2013) in a related context. We associate three outcomes with each of our three propositions related to migration explanations and consequences. We then estimate the number of cases that fit each outcome.

We study 14 cases, a larger sample than that generally used in this approach, to consider Mason and Harrison's (2006, p.58) observation that both the reasons for and effects of acquisitions usually differ widely, depending notably on the type of acquiring company, acquirer and acquisition.

\section{Previous literature, propositions, and expected pattern}

\section{Extent of the phenomenon}

Several studies analyse VC exits, but generally neglect to consider the country where the NTBF develops after the exit, and focus on differences between IPOs, trade sales and liquidation (Schwienbacher, 2005; Brander et al., 2010; Ball et al., 2011; Espenlaub et al., 2014). Schwienbacher (2005) reports the frequency of the different exit routes for US VCs and presents a proportion of initial public offerings (IPOs) of 29.9\%. In Canada, Brander et al. (2010) evidence a proportion of exit by IPO on a senior (junior) exchange of $1.8 \%$ (1.3\%). The trade sale is becoming, by far, the most common exit mode from successful VC investments. This is not limited to Canada: in other small countries like Israel (Teubal and Avnimelech, 2003) and New Zealand (Davenport, 2009), trade sales are distinctive in that the acquirers are predominantly foreign firms. Further, trade sales become FTS with potentially negative crowding-out effects. However, this phenomenon remains largely unexplored.

The first important question is how often successful VC-backed NTBFs are sold to foreign firms or investors. Second, previous empirical evidence indicates that innovative, fast-growing businesses are more likely to be bid targets (Mason and Harrison, 2006; Foreman-Peck and 
Nicholls, 2013). It thus becomes important to determine what proportion of the most promising VC-backed NTBF migrates. These two questions constitute the first dimension of the phenomenon.

\section{Migration motivations}

Migration is not an entirely new topic, although most previous works focus on within-border changes of localisation. Two propositions emerge from the research and from Canadian reports. First, firms can move abroad because of managers' strategic decisions. Alternatively, some firms are obliged to move abroad.

Strategic motivation

The institutional approach suggests that firm location behaviour is "the result of firm's investment strategies” (Brouwer et al., 2004 p.337). External or institutional factors including expansion, merger, acquisition and take-over, co-operation and convention play a central role to explain the relocation decision. For high-tech firms, migration should be required to develop networks and R\&D collaboration, and to establish close links with specialised research centres. Second, innovative firms are likely to move to large markets, where specialised innovative products or services can be profitably launched (Rosenberg, 2002; Jones et al., 2011). The FTS can be a manager's strategic choice to reduce the liability of foreignness and the other risks and costs following international expansion (Coeurderoy et al., (2012). Third, due to an ongoing change in the economy, small firms are worth more as part of a larger organisation (Ritter et al., 2013). Established firms can rapidly commercialise high-tech products and services and realise economies of scope and scale. Small firm shareholders find it more convenient and profitable to get big fast by selling out in a trade sale rather than going public and remaining independent 
(Achleitner et al., 2014; Carpentier and Suret, 2014). In Canada, Doyle et al. (2004) and the Expert Panel (2009) contend that emerging high-tech firms will often be sold to foreign strategic acquirers because of the scarcity of large domestic technology firms. The first proposition to explain the FTS is

$\mathrm{P}_{1}$ : FTS are the result of strategic considerations.

If this proposition is true, we should evidence the following pattern and corresponding outcomes:

$\mathrm{O}_{1.1}$ : The buyer is a firm in the same sector as the acquired firm.

$\mathrm{O}_{1.2}$ : The reasons for the transactions are mainly market- or network-related.

$\mathrm{O}_{1.3}$ : The transaction is motivated by complementarity or synergy effects.

\section{Financing Gap}

The alternative proposition rests on the premise that Canadian emerging firms migrate because they face a financing gap. This gap could result from several weaknesses of the Canadian VC market (Expert Panel, 2009; Jenkins, 2011; Hurwitz and Marett, 2012). The inability of Canadian operating companies to obtain sufficient capital to expand, which implies they must be sold before they attain market leadership, often to large US companies, is affirmed by the OECD (2010 p.63). In other countries, scant local VC also explains why NTBF turn toward foreign VCs, who are more likely to organise a foreign exit (Mäkelä and Maula, 2005; Gonzalo et al., 2013). If FTS result from a local financing gap, we should observe that local VCs have not funded the firm recently. Foreign VCs are likely to be involved in the latest rounds of financing, and the quest for finance should be cited by managers and the main shareholders to explain the decisions. The second proposition to explain FTS is:

$\mathrm{P}_{2}$ : Local financing gaps explain FTS.

If this proposition is true, we should see the following pattern and corresponding outcomes: 
$\mathrm{O}_{2.1}$ : Acquired firms have not been financed locally during the two years before the acquisition.

$\mathrm{O}_{2.2}$ : Foreign VCs are involved in the latest financing round.

$\mathrm{O}_{2.3}$ : The managers of the acquired firm mention the financial limitation on growth.

\section{Consequences}

The overall impact of cross-border acquisitions has been largely debated without reaching a consensus. As underlined by Grant and Bloom (2008), the takeover effects depend on the postacquisition decisions made by the new owners, and can result in a wide range of positive, negative, or neutral effects. We consider three dimensions: i) consequences on R\&D, production and innovation, ii) the loss of complete firms and potential leaders and iii) the recycling effect. Technology transfer and spillover productivity effects could be observed via the dissemination of innovations on locally owned firms, when the NTBF's R\&D activities expand following the acquisition. This depends on the acquirer's willingness to tap into the innovative resources of a region. Regions experiencing rapid technological development could contain considerable tacit knowledge that can attract large foreign firms. In such cases, the acquisition can let acquirers anchor their activities in the region (Dahlstrand, 2000). Delocalisation of R\&D activity also depends on the embedding of the NTBF research team in the local network of tacit knowledge, a critical component of the development process (Reynolds et al., 2014). Tacit knowledge requires proximity and face-to-face interactions, is context-specific and is thus a key determinant of the geography of innovation (Gertler, 2003). This knowledge is "sticky" and thus less mobile and harder to communicate over distances. Stickiness has historically protected work from easily being offshored (Reynolds et al., 2014). Most of our studied firms operate in the information technology sector. Clusters of this type of technology exist in Canada (Lucas et al., (2009). However, only one of our cases can be considered as coming from one of these clusters. 
Accordingly, the technology spillover effect is likely to be weak and the crowding-out effect significant following the acquisition, consistent with the strategy of large US firms that have a relatively low proportion of R\&D and patenting activity abroad (Narula and Zanfei, 2005).

Even if we do not expect large R\&D spillover, the acquisition could have positive effects if the acquired firm develops as a stand-alone entity. In Sweden foreign acquisitions have positive effects, probably because large firms let acquired SME retain their autonomy (Dahlstrand, 2000). In Canada, Doyle et al. (2004) find that the acquirers usually maintain only a small part of the bought-out firms' activity in the original country as a truncated company or simply move the activity abroad. Truncated entities are left with only an R\&D function, and lack the head offices, production, sales and finance functions that potentially generate significant economic activity. Moreover, the Canadian and US markets are closely integrated and US firms can easily reach Canadian customers. Accordingly, based on previous observations, we expect to observe that acquired NTBFs became truncated companies.

Analysing the acquisition of NTBF by larger firms located in central areas, Mason and Harrison (2006) contend that the entrepreneurial recycling benefits are likely to offset the crowding-out effect. Recycling occurs if bought-out owners of SMEs become serial entrepreneurs or business angels and recycle the outcome of the acquisition in new ventures. We expect to observe a different situation in our sample for two main reasons. First, VC are largely involved in the financing of the bought-out firms, for an average amount of CAN\$21.2 million. The amounts received by the entrepreneurs are thus likely to be smaller than in the cases analysed by Mason and Harrison (2006). Second, acquisition by a foreign firm is likely to induce some entrepreneurs to leave the country if the buyer transfers the NTBF activities. Our proposition concerning migration effects is: 
$\mathrm{P}_{3}$ : FTS have globally negative effects in Canada.

If this proposition is valid, we should see the following pattern and corresponding outcomes:

$\mathrm{O}_{3.1}$ : The R\&D activity of acquired NTBFs does not increase following the acquisition.

$\mathrm{O}_{3.2}$ : The acquired Canadian NTBFs become truncated companies.

$\mathrm{O}_{3.3}$ : There is little evidence of local recycling activities.

\section{Data}

We used two sources to quantify the extent of FTS. Thomson Reuter's Private Equity and Venture Capital service provides information on VC deals and exits. ${ }^{4}$ We used this source to construct a list of 712 VC exits from Canadian firms between 2001 and 2012. We determined the nationality of the buyer in each trade sale, and the stock exchange in each IPO. We also compiled a list of the "Deals of the year." The Canadian Venture Capital \& Private Equity Association (CVCA)'s Deal of the Year Award competition promotes, highlights and celebrates the achievements of members with the most significant investment returns during the last twelve months. We used this list to identify the most promising VC-backed firms. We collected the information in the CVCA's press releases from 2005 to 2012.

We attempted to reflect the diversity of the phenomenon in the choice of cases. We selected the 14 firms that migrate following a FTS from the lists constructed for the quantitative analysis and that satisfy the following conditions: i) be associated with high technology activities, ii) be financed initially by Canadian VCs, for a minimal amount of CAN\$1 million, iii) have been sold to foreign interest after a minimal local existence of two years, and iv) have been followed by the media and have provided enough information to be analysed. We attempted to select acquisition dates that were not clustered, but that cover the years 2000-2010. We restricted our selection to firms initially located in the Province of Quebec for two reasons. First, in this province, the 
Governments implemented several actions to increase the supply of VC, purportedly to foster local economic development. As a result, more than half of the Canadian VC was managed by Quebec funds in the early 2000s; government, quasi-government and tax incentivised laboursponsored VCs predominated in this province. Studying the economic impact of VC exits is thus particularly relevant in this context. Second, we restrict the study to one Canadian province to identify local consequences more easily.

To extract qualitative data, we first collected all information available since the inception of the firms, including each financing round announcement, press releases and newspaper articles dedicated to NTBF and entrepreneurs, and to their statements surrounding the event. We also obtained the filings of public buyers. We devoted special attention to information on trade sales, and we noted the manager's announcement at the transaction time. We followed each case until mid-2013, to track the outcome of each target firm, and the activities of the bought-out entrepreneurs following the transaction. For firms surviving locally, we determined the level of revenues at FTS time and in 2012. We used Factiva and specialised websites (including Manta.com and Industry Canada), and releases issued by the CVCA. We also summarised the information related to the products, for both the target and the acquirer, and determined the NAICS codes of both firms involved in the transaction. Several key members of the team before the migration had left the firms and could not be easily interviewed. We used press releases, LinkedIn and Factiva to determine the entrepreneurs' activities following the transaction. Case studies were thus mainly based on archival data. We contacted the remaining Canadian entities by phone to determine the current number of employees and the fate of the acquired entities.

In a second step, we searched for financing rounds and the information related to each of the private equity investors involved in the financing, distinguishing between private and 
government-sponsored funds. We analysed each target's evolution, financing and innovation in detail. Third, we gathered all discourse related to the migration reasons mentioned by the entrepreneurs, the acquirers or the VCs. Each sentence was situated in a grid based on the outcome defined above. This was done independently by both researchers and a research professional. Cases of divergences in coding and interpretations were very few, and were solved by discussion. During the last step of the process, we determined if each case satisfied the expected patterns associated with the propositions.

\section{Results}

\section{Extent of the phenomenon}

In Table 1, we report the numbers and proportions of domestic trade sales, FTS, domestic IPOs, and foreign and cross-listed IPOs. In Canada, trade sales and IPOs constitute respectively 78\% and $13 \%$ of reported successful VC exits. Other types of exits include backdoor listings (reverse mergers) and secondary sales, accounting for $4 \%$ of the exits. Because the foreign exits reported in this group comprise $1.5 \%$ of the total sample, we do not analyse this type of exit in detail. Write-offs account for a meagre $5 \%$ of the exits because most are not reported.

IPOs are mainly launched on the domestic market $(10 \%)$, and foreign and cross-listed IPOs account for $2 \%$ of the exit over the whole period; they can be considered as a marginal source of migration. Trade sales predominate among successful exits. Because most involve foreign buyers (314 vs. 240 Canadian buyers), FTS are clearly the major source of migration. When foreign IPOs are accounted for, the proportion of VC-backed firms that migrate reached $45 \%$ between 2001 and 2012.The proportion of FTS increases from 42\% to 46\% between the years 2001-2006 and 2007-2012 and, overall, the proportion of foreign exits including IPOs was 48\%. Nearly half of the successful VC exits from Canadian firms result in migration. Trade sales constitute $75 \%$ of 
exits during the first sub-period and $81 \%$ thereafter. Exit through trade sale is becoming, by far, VCs’ preferred exit mode.

\section{Insert Table 1 here}

The Deals of the Year are summarized in Appendix 1. The most successful NTBFs are indeed sold to foreign firms. Six of the eight most successful exits of the VC industry in Canada since 2005 involve a foreign strategic investor. In one case, the firm moved to the US following a listing on the NASDAQ. The only very successful domestic exit is in the natural resource sector. Since 2005 in Canada, each of the most successful VC-backed NTBFs has moved abroad and none could become a large Canadian firm. Migration is thus an increasingly important phenomenon in Canada.

Survey of bought-out firms

The evolution of the 14 firms is summarised in Table $2 .{ }^{5}$ Six firms are more than nine years old, and only one is less than four years old. This is an expected result, because we select situations of exit by VCs, an operation that generally occurs after four to seven years of participation. With few exceptions, the studied firms operate in the information and communications technologies (ICT) sector, in line with the strong participation of Canadian VC in this sector, which accounts for $49 \%$ of VC investment in 2008 and $53 \%$ in 2009.

We have listed the financing rounds and the funds involved in each of these rounds. Because a firm may receive equity from several sources at each financing round, the total number of financings is 32. Six firms received only one round of VC funds, and four firms received two successive rounds. The median length between the initial financing and the exit is three years. The time to exit of Canadian VCs is short by North American standards. Peters (2009 p.40) 
asserts that this time has increased from four to eight years from 2000 to 2008. Two subsets of VCs are involved in the financing of the studied firms. Government-sponsored VC funds provided financing in 29 cases, while private VCs, including US firms, invested in 23 cases. This situation reflects the strong government involvement in the Quebec VC industry.

Table 2 briefly describes the buyers. All are US-based high tech firms, including three subsidiaries of large firms: EADS, UTC and HP. The other buyers are small- and medium-sized firms according to the US terminology. In two cases, the acquirers are private companies created respectively one and five years before the acquisition. In eight cases, we determined the buyer's total assets. They are below US\$50 million in two cases, between US\$50 and US\$200 million in three cases, and between US\$200 and US\$700 million in three acquisitions. In one case, we accessed the revenues only, estimated at US\$253 million. This suggests total assets lower than US\$200 million.

\section{Insert Table 2 here}

\section{FTS motivations}

Using the comprehensive list of citations and the characteristics of the deal, we determine the extent that the expected patterns associated with our propositions could be affirmed. Table 3 summarises our results related to FTS motivations.

In each of the 14 cases, we compare the industrial codes and find that the acquirer operates in the same industry as the target. Moreover, the services or products of both firms are generally very close. For example, Haptic Technologies was acquired by Immersion Corp, a Californian direct competitor of Haptic. Tomoye Corp. was acquired by Newsgator. Both firms have developed editors that improve the use of Microsoft Sharepoint by embedding social media functionalities. $\mathrm{O}_{1.1}$ is then satisfied in each case. 
In seven of the 14 cases, we find explicit mention of market consideration $\left(\mathrm{O}_{1.2}\right)$ in the entrepreneur's or acquirer's declaration. We report excerpts from these references in Table 3 column 3. For example, one CEO mentioned: "I am excited about the combined capabilities of Carrier and Micro Thermo. With Carrier's heritage, brand image and global presence, they provide the perfect platform to expand and improve our customer service in North America and abroad.” The Movibox founder says: "We're very proud that Sabse Technologies values so highly the voice-services-development environment we've carefully nurtured. We look forward to working closely with Yogesh and his team to bring voice-activated services to carriers and their customers around the world."

The comment that the acquired firms will benefit from the acquirer's infrastructure to access the market is less common (7 cases) than explicit references to product or service complementarities, detected in all 14 cases. Complementarities were notably mentioned by Mycota Bioscience’s CEO: "Elitra's expertise in bioinformatics and high throughput screening provides the ideal platform for furthering the development of Mycota's scientific accomplishments. Additionally, we believe that our gene discovery and drug screening technologies are very complementary, and together we can leverage the knowledge gained from Candida Albicans to advance programs on other major human and agrochemical fungal pathogens.” When Ramtron International acquired Goal semiconductor, its CEO announced: "We expect that this acquisition, which is highly complementary to our current product strategy, will give us a five-year jump on our roadmap for integrated and application-specific product launches. As a result, we hope to accelerate the development and delivery of high-margin products targeted at the markets that we serve.” The Carrier’s Vice-President mentions: “This acquisition enables Carrier to offer a complete range of controls products and software to satisfy the needs of food retailers with an intuitive, easy-to-use 
system to manage operations and develop strategies to lower costs, particularly in light of rising energy prices. Carrier, through its various subsidiaries, already provides a broad array of refrigeration and HVAC equipment to supermarkets; Micro Thermo complements our current businesses and enables our company to provide a full range of products and services to individual stores and chains.” At the time of the acquisition of Colubris network, the Senior Vice-president of HP ProCurve says: “The acquisition of Colubris Networks will strengthen ProCurve's hardware, management platform and services, significantly improving the overall performance capabilities of both wired and wireless networks, and will deliver even more best-in-class choices for our customers worldwide.” Similar declarations can be found in each studied case (Table 3). $\mathrm{O}_{1.3}$ is thus satisfied in all cases.

Overall, our studied cases fit the expected pattern associated with $\mathrm{P}_{1}$. The expected outcomes according to this pattern are observed in 35 of 42 possibilities. The studied FTSs seem to be linked to strategic considerations.

The three rightmost columns of Table 3 report our observations on the outcomes of the expected pattern linked to proposition 2. $\mathrm{O}_{2.1}$ states that acquired firms have not been financed locally during the two years before the FTS. Only five cases satisfy this outcome, but this number is reduced to three if we expand the time frame up to 2.5 years. Most of the firms that do not get VC financing during the two years before the FTS report revenues at this time. This can explain why they did not attempt to obtain a new round of external equity.

Foreign VCs are involved in two firms, but play a significant role in only one case (Colubris). In the other case, the foreign investor co-invests with five local funds, for a total amount of CAN\$20 million. Foreign VCs invest jointly with local investors, and do not seem to supersede local VCs. Their involvement can be traced to the large amounts requested by the firms, which 
received a total of CAN\$66 million and CAN\$20 million respectively. Accordingly, $\mathrm{O}_{2.2}$ is not supported in nearly all of the studied cases. However, we observe evidence of recourse to US VCs when the requested amounts rise. We consider that $\mathrm{O}_{2.2}$ is generally not satisfied.

We do not find any explicit mention of shortage of funds in any case. $\mathrm{O}_{2.3}$ is thus not affirmed. Overall, the 42 expected outcomes are observed in 7 cases only, for a proportion of $17 \%$. The proposition that firms migrate because they face a shortage of equity financing is thus inconsistent with the cases we analyse. Our observations support the strategic explanation of migration. Canadian high tech firms studied joined larger firms producing complementary or similar goods or services in the same sectors. They primarily sought synergetic effects and aimed to reach a large market more easily than they could as a stand-alone entity. The acquirers aspired to offer their customers more services or products.

\section{Insert Table 3 here}

\section{Consequences}

Table 4 summarises our observations on the outcomes associated with the expected pattern, i.e. that FTS have negative effects. We analyse the fate of the bought-out entities. Nonetheless, comprehensive information is generally out of reach because the acquired firms are mainly subsidiaries of private entities.

In ten cases, the acquired company no longer operated at the initial location, although in four of these cases, the acquirer had an office in Canada. In one case, the R\&D team was integrated with the buyer's team in the same city. In three cases, the acquired firm continued R\&D activities, albeit on a small scale. In each case, we estimated the revenues in 2012 and those reported at the FTS time. The latter are similar to or lower than the former, at between \$1 million and \$10 million. The growth rate of $R \& D$ activities, which are the sole source of revenues for these 
entities, is approximately 0 . Accordingly, we consider that none of the acquired firm exhibits significant growth in R\&D activities, which could generate spillover effects. $\mathrm{O}_{3.1}$ is thus observed in all the studied cases.

Overall, 10 of 14 (71\%) NTBFs acquired by foreign firms disappeared. We observe that the four surviving entities resulting from acquisitions fit the definition of truncated company proposed by Doyle et al. (2004 p.9). None reported activities other than R\&D. The truncated company was left with only an R\&D function, whereas the acquirer had its own sales, marketing and production department, and a head office. These NTBFs failed to develop as stand-alone entities. Accordingly, $\mathrm{O}_{3.2}$ is systematically affirmed. The studied FTS appear to have systematic negative effects on local economic development.

The right part of Table 4 summarises our observations about a possible recycling effect of FTS that could offset the negative consequences evidenced above. Only 2 of 14 cases could generate this effect, when the entrepreneurs subsequently founded new NTBFs. Both fit the definition of serial entrepreneurs. Four entrepreneurs have recycled their experience, becoming a consultant, CEO or involved in VC, but they did not create new ventures. The other entrepreneurs created new ventures in other provinces or countries, were still employed by the acquirer, or had left the business world. These results differ from those observed in another context by Mason and Harrison (2006) in Scotland. They can be traced to heavy involvement of VC before the FTS. Notably, VC could have captured much of the sale proceeds. A full analysis should consider the recycling of these funds, but we think that the economic effect of capital recycling may be weak because local VC abound: according to the Quebec Venture Capital Association, ${ }^{6}$ in 2000 the total pool of VC under management was $\$ 8.6$ billion, a proportion of GDP far higher than in the US, and the liquidity of Québec-based VCs was estimated at \$2 billion. Accordingly, the 
amounts collected through FTS are unlikely to change the investment propensity of the local VC funds.

\section{Insert Table 4 here}

\section{Conclusion and implications}

Our analysis points to three important conclusions. First, in Canada, the VC industry, including government-sponsored funds, is a significant source of migration of promising NTBF to the US, and does not seem to fully play the positive role described by Kenney (2011) in other countries. Second, the NTBF migration is motivated largely by strategic considerations, in the context of a small country where the number of strategic partners is limited and the market for innovative products is also considered small. Like their counterparts in other countries, Canadian VCs prefer to exit through trade sales but cannot find a local acquirer easily. VC-backed IPOs, which are often prerequisites to the construction of large public firms, have become exceptional events. This situation is particularly worrying in Canada, where the number of large technological companies is small and decreasing. This reduces the likelihood of the emergence of new technological leaders, clusters and networks that can ease local exits. We observe less positive effects of acquisitions than do previous studies, for two reasons. Unlike the case in South America (Gonzalo et al., 2013) or in some European countries (Dahlstrand, 2000), the acquisition did not reinforce local activity. The acquired firms became truncated companies, and often simply disappeared. Third, only a small proportion of the bought-out entrepreneurs were involved in creating new local NTBF. They were largely serial entrepreneurs with a clear strategy of quick exit, often by FTS. The recycling effect described by Mason and Harrison (2006) does not seems to work in Canada. Our results concern a Canadian province where the governments 
implemented several major actions to stimulate the VC industry, with a clear objective of promoting local economic development.

The role and responsibility of the VC industry in a small open economy deserves attention and should be analysed in other contexts. As underlined by Niosi (2000, p.9), financial institutions that provide funding for innovation are a major component of the national innovation system. Their role in this context has not been analysed, especially in small countries where, despite great effort, VCs are still not a significant component of the national innovation system (Kenney, 2011 p.1679). The reasons why high growth firms move abroad, the consequences of such migrations, and the policy tools that can prevent their systematic migration are important research topics. Our study deals with a particular context, and cannot be extrapolated to other regions. However, we provide evidence supporting several claims by panel experts and academics in Canada.

Another implication of our study is that the process of globalisation is likely to influence the design and implementation of innovation policies (Edquist, 2011 p.1726). Canada has devoted significant resources to structure and help the VC industry; nearly half of the industry receives government funds or tax advantages. To our knowledge, the overall performance of this industry in terms of the creation of local industrial or R\&D leaders has not been examined. We evidence that most of the exits, including the most profitable ones, generally involve foreign buyers. This can be explained by the paucity of large Canadian high tech firms. The VC industry does not seem to be increasing the number of such companies.

What can be done in terms of public policy to obviate the migration problem in Canada? There is no easy answer to this question because the motivations for migration are linked to strategic factors. However, the literature on international entrepreneurship, along with the evolution of Canadian firms like Nortel and RIM, indicates that development of high tech firms in Canada is 
possible. We suggest that the focus be changed from the number of start-ups financed to the number and quality of large firms created by the process. Overall, we consider that the migration of vital capabilities can undermine innovation capacity, (Reynolds et al., 2014). This phenomenon-should be analysed more deeply. 


\section{Notes}

${ }^{1}$ Conference Board of Canada, available at: http://www.conferenceboard.ca/hcp/details/innovation.aspx. In Sweden, a similar phenomenon is known as the Swedish Paradox (Ejermo and Kander, 2006).

${ }^{2}$ Silcoff S and Marlow I, The Globe and Mail, Canada's vanishing tech sector, Accessed online 2014 April, 10, http://www.theglobeandmail.com/report-on-business/economy/canada-competes/canadasvanishing-tech-sector/article4396596/?page $=$ all

${ }^{3}$ See: Foreign Acquisition in Canada's Tech Sector: Lack of Domestic Investment Drives Away Homegrown Startups, Pang Y, Epoch Times Staff, accessed online April 10, 2014 at http://www.theepochtimes.com/n2/canada/foreign-acquisition-in-canadas-tech-sector-274143.html or Is Canada's tech sector "vanishing”?, McQueen M, accessed online April 10, 2014 at http://www.wellingtonfund.com/blog/2012/07/09/is-canadas-tech-sector-vanishing/\#axzz24CjDDIpc, or Who will be Canada's next tech darling?, Schwartz D, accessed online April 10, 2014 http://www.cbc.ca/news/technology/story/2012/07/12/f-canadian-technology-industry.html.

${ }^{4}$ This source is generally used to summarise VC activity in Canada, including the quarterly and annual reports published by the CVCA. The information comes mainly from VCs, who tend to report only the successful exits.

${ }^{5}$ The detailed analysis (31 pages) is available upon request but it cannot be included in the article, owing to the Journal's size requirements.

${ }^{6}$ Réseau Capital, The Venture Capital Industry in Québec in 2000: An Overview, Available at: http://www.reseaucapital.com/docs/comments_2000.pdf, accessed online April 10, 2014

\section{References}

Achleitner A-K, Braun R, Lutz E and Reiner U (2014) Industry Relatedness in Trade Sales and Venture Capital Investment Returns. Small Business Economics Forthcoming

Anokhin S (2013) Venture Migration: a Quest for a Low-hanging Fruit? Entrepreneurship \& Regional Development 25(5-6): 423-445

Ball E, Chiu HH and Smith R (2011) Can VCs Time the Market? An Analysis of Exit Choice for Venture-backed Firms. Review of Financial Studies 24(9): 3105-3138

Baygan G (2003). Venture Capital Policies in Canada. OECD Science, Technology and Industry Working Papers, 2003/4, OECD Publishing. 18 p.

Bena J and Li K (2013) Corporate Innovations and Mergers and Acquisitions. The Journal of Finance Forthcoming

Bertoni F and Groh A (2014) Cross-Border Investments and Venture Capital Exits in Europe. Corporate Governance: An International Review 22(2): 84-99

Bitektine A (2008) Prospective Case Study Design: Qualitative Method for Deductive Theory Testing. Organizational Research Methods 11(1): 160-180

Brander JA, Egan E and Hellmann TF (2010). The Comparative Performance of Government Sponsored and Private Venture Capital: An Investigation using Canadian Data. International Differences in Entrepreneurship J. Lerner and A. Schoar. Chicago: The University of Chicago Press.

Brouwer AE, Mariotti I and van Ommeren JN (2004) The Firm Relocation Decision: An Empirical Investigation. The Annals of Regional Science 38(2): 335-347

Carpentier C and Suret J-M (2014) Canadian Business Angel Perspectives on Exit: A Research Note. International Small Business Journal Forthcoming 
Coeurderoy R, Cowling M, Licht G and Murray G (2012) Young Firm Internationalization and Survival: Empirical Tests on a Panel of 'adolescent' New Technology-based Firms in Germany and the UK. International Small Business Journal 30(5): 472-492

Dahlstrand AL (2000). Large Firm Acquisitions, Spin-offs and Links in the Development of Regional Clusters of Technology intensive SMEs. Hightechnology Clusters, Networking and Collective Learning in Europe. D. Keeble \& F. Wilkinson (Eds.). Ashgate Aldershot: 156-181.

Davenport S (2009). Where Does International Entrepreneurship End?: Exploring Entrepreneurial Exit from Internationalised SMEs Through Trade Sales. Working Paper, Victoria Management School

Doyle D, McDougall G and Doyle J (2004). Building Word Class Canadian High Tech Companies. Report Prepared by Doyletech Corp. for the Information Technology Association of Canada

Dul J and Hak T (2008). Case Study Methodology in Business Research. Burlington, Routledge.

Edquist C (2011) Design of innovation policy through diagnostic analysis: identification of systemic problems (or failures). Industrial and Corporate Change 20(6): 1725-1753

Ejermo O and Kander A (2006). The Swedish Paradox. CIRCLE Electronic Working Paper Series. Lund, Sweden:

Enderwick P and Scott-Kennel J (2009). New Zealand and the Challenge of Global Competition. Handbook On Small Nations In The Global Economy: The Contribution of Multinational Enterprises to National Economic Success. D Van den Bulcke A Verbeke and W Yuan ed: Edward Elgar Publishing Limited.

Espenlaub S, Khurshed A and Mohamed A (2014) VC Investments and Global Exits. The European Journal of Finance: 1-21

Expert Panel (2009). Innovation and Business Strategy: why Canada Falls Short. Expert Panel on Business Innovation: Report for the Minister of Industry by the Council of Canadian Academies

Fagerberg J and Srholec M (2008) National Innovation Systems, Capabilities and Economic Development. Research Policy 37(9): 1417-1435

Foreman-Peck J and Nicholls T (2013) SME Takeovers as a Contributor to Regional Productivity Gaps. Small Business Economics 41(2): 359-378

Freeman C and Soete L (2009) Developing Science, Technology and Innovation Indicators: What we can Learn from the Past. Research Policy 38(4): 583-589

Gertler MS (2003) Tacit Knowledge and the Economic Geography of Context, or The Undefinable Tacitness of Being (There). Journal of Economic Geography 3(1): 75-99

Gonzalo M, Federico J, Drucaroff S and Kantis H (2013) Post-investment Trajectories of Latin American Young Technology-based Firms: an Exploratory Study. Venture Capital 15(2): $115-133$

Grant M and Bloom M (2008). "Hollowing Out”-Myth and Reality: Corporate Takeovers in an Age of Transformation. The Conference Board of Canada

Groh A, Liechtenstein H and Lieser K (2012). The Global Venture Capital and Private Equity Country Attractiveness Index: 2011 Annual. Universidad de Navarra, International Center for Financial Research, Available at http://www.iese.edu/research/pdfs/estudio-143-e.pdf

Hurwitz SA and Marett LJ (2012). Financing Canadian Innovation: Why Canada Should End Roadblocks to Foreign Private Equity. CD Howe Institute Commentary 244 
Hyde KF (2000) Recognising Deductive Processes in Qualitative Research. Qualitative market research: An international Journal 3(2): 82-90

Jenkins T (2011). Innovation Canada: A Call to Action. Report of the Expert Panel Commissioned by the Federal Government to Review Federal Support for Research and Development, Under the Chairmanship of Tom Jenkins Ottawa: Publishing and Depository Services, Public Works and Government

Jones MV, Coviello N and Tang YK (2011) International Entrepreneurship Research (19892009): A domain Ontology and Thematic Analysis. Journal of Business Venturing 26(6): 623-659

Kenney M (2011) How Venture Capital Became a Component of the US National System of Innovation. Industrial and Corporate Change 20(6): 1677-1723

Langford CH, Josty P and Holbrook JA (2014). 2013 GEM Canada National Report. The Centre for Innovation Studies (THECIS)

Lucas M, Sands A and Wolfe DA (2009) Regional Clusters in a Global Industry: ICT Clusters in Canada. European Planning Studies 17(2): 189-209

Mäkelä MM and Maula MVJ (2005) Cross-border Venture Capital and New Venture Internationalization: An Isomorphism Perspective. Venture Capital 7(3): 227-257

Mäkelä MM and Maula MVJ (2008) Attracting Cross-Border Venture Capital: the Role of a Local Investor. Entrepreneurship \& Regional Development 20(3): 237-257

Mason C and Harrison R (2006) After the Exit: Acquisitions, Entrepreneurial Recycling and Regional Economic Development. Regional Studies 40(1): 55-73

Molina-Azorín JF, López-Gamero MD, Pereira-Moliner J and Pertusa-Ortega EM (2011) Mixed Methods Sudies in Etrepreneurship Resesarch: Applications and Contributions. Entrepreneurship \& Regional Development 24(5-6): 425-456

Narula R and Zanfei A (2005). Globalisation of Innovation. Handbook of Innovation. J. Fagenberg D. Mowery and R. Nelson (Eds). Oxford: Oxford University Press: 318-345.

Niosi J (2000). Canada's National System of Innovation. Montreal, McGill-Queen's University Press.

OECD (2010). CANADA. OECD Economic Surveys, Vol 2010/14

OECD (2012). Education at a Glance 2012: OECD Indicators. Directorate for Education and Skills, OECD Indicators

Peters B (2009). Early Exits: Exit Strategies for Entrepreneurs and Angel Investors (but Maybe not Venture Capitalists), MeteorBYtes Data Management Corp.

Reynolds EB, Samel HM and Lawrence J (2014). Learning by Building: Complementary Assets and the Migration of Capabilities in US Innovative Firms. Production in the Innovation Economy. Richard M. Locke and Rachel L. Wellhausen (Eds). Cambridge MA MIT Press 81-.

Ritter JR, Gao X and Zhu Z (2013) Where Have All the IPOs Gone? Journal of Financial and Quantitative Analysis Forthcoming

Rosenberg D (2002). Cloning Silicon Valley: the Next Generation High-tech Hotspots. London, Pearson Education.

Schwienbacher A (2005). An Empirical Analysis of Venture Capital Exits in Europe and the United States. EFA 2002 Berlin Meetings Discussion Paper

Scott-Kennel J (2013) Selling to Foreign MNEs. International Studies of Management \& Organization 43(1): 52-80 
Taylor M and Jack R (2013) Understanding the Pace, Scale and Pattern of Firm Internationalization: An Extension of the 'Born global' Concept. International Small Business Journal 31(6): 701-721

Teubal M and Avnimelech G (2003) Foreign Acquisitions and R\&D Leverage in High Tech Industries of Peripheral Economies. Lessons and Policy Issues from the Israeli Experiences. International Journal of Technology Management 26(2): 362-385

Yin RK (2014). Case Study Research : Design and Methods (Fifth Edition). Thousand Oaks, Sage Publications. 


\section{Tables}

Table 1 Distribution of VC exits from Canadian firms reported by Thomson Reuter, 20012012, according to exit type and exit location. \# means number of exits, \% means percent of the total exit number.

\begin{tabular}{|c|c|c|c|c|c|c|}
\hline & & 2012 & & 2006 & & 2012 \\
\hline & \# & $\%$ & \# & $\%$ & \# & $\%$ \\
\hline Initial public offe & & & & & & \\
\hline Canadian & 74 & $10 \%$ & 54 & $15 \%$ & 20 & $6 \%$ \\
\hline TSX & 57 & $8 \%$ & 41 & $11 \%$ & 16 & $5 \%$ \\
\hline TSXV & 17 & $2 \%$ & 13 & $4 \%$ & 4 & $1 \%$ \\
\hline Non-Canadian & 10 & $1 \%$ & 4 & $1 \%$ & 6 & $2 \%$ \\
\hline Cross-listing & 7 & $1 \%$ & 4 & $1 \%$ & 3 & $1 \%$ \\
\hline Total & 91 & $13 \%$ & 62 & $17 \%$ & 29 & $8 \%$ \\
\hline Trade sale & & & & & & \\
\hline Canadian & 240 & $34 \%$ & 117 & $33 \%$ & 123 & $35 \%$ \\
\hline Non-Canadian & 314 & $44 \%$ & 152 & $42 \%$ & 162 & $46 \%$ \\
\hline US & 240 & $34 \%$ & 118 & $33 \%$ & 122 & $34 \%$ \\
\hline Non-US & 74 & $10 \%$ & 34 & $9 \%$ & 40 & $11 \%$ \\
\hline Total & 554 & $78 \%$ & 269 & $75 \%$ & 285 & $81 \%$ \\
\hline Other & & & & & & \\
\hline Canadian & 18 & $3 \%$ & 3 & $1 \%$ & 15 & $4 \%$ \\
\hline Non-Canadian & 11 & $2 \%$ & 3 & $1 \%$ & 8 & $2 \%$ \\
\hline US & 9 & $1 \%$ & 3 & $1 \%$ & 6 & $2 \%$ \\
\hline Non-US & 2 & $0 \%$ & 0 & $0 \%$ & 2 & $1 \%$ \\
\hline Total & 29 & $4 \%$ & 6 & $2 \%$ & 23 & $6 \%$ \\
\hline Write Off & 38 & $5 \%$ & 21 & $6 \%$ & 17 & $5 \%$ \\
\hline Total & 712 & $100 \%$ & 358 & $100 \%$ & 354 & $100 \%$ \\
\hline
\end{tabular}


Table 2 Characteristics of the studied NTBF. \$M (US\$M) means millions of Canadian (US) dollars. Gov. (priv.) means government-sponsored (private) venture capitalist. IC means Industry Canada. The age (location) is that of the company (head office) at the acquisition time. In the column labelled "financing rounds", amounts are that of raised financings. The amount in the column entitled "US acquirer and acquisition date” is the acquisition price, if available, and the values between brackets are acquirers' total assets before the transaction, or revenues (rev.) or creation date if total assets were not available. NA means not available.

\begin{tabular}{|c|c|c|c|c|}
\hline Company name & Product or service & Age and location & Financing rounds & $\begin{array}{l}\text { US acquirer and } \\
\text { acquisition date }\end{array}$ \\
\hline $\begin{array}{l}\text { Pyderion } \\
\text { Contact } \\
\text { Technologies } \\
\text { Inc. }\end{array}$ & $\begin{array}{l}\text { Software managing e- } \\
\text { commerce call centres }\end{array}$ & $\begin{array}{l}13 \text { years, } \\
\text { Montréal }\end{array}$ & $\begin{array}{l}\text { round 1: } \$ M 2 \text {, } \\
\text { round 2: } \$ M 2.2 \text {, } \\
1 \text { gov. and } 2 \text { priv. }\end{array}$ & $\begin{array}{l}\text { Intecom (NA), } \\
\text { subsidiary of EADS } \\
\text { (Euronext), Dec 29, } \\
2000\end{array}$ \\
\hline Movibox Corp. & $\begin{array}{l}\text { Voice over internet } \\
\text { protocol (VoIP) calls for } \\
\text { mobile phones }\end{array}$ & $\begin{array}{l}2 \text { years, } \\
\text { Montréal }\end{array}$ & $\begin{array}{l}\text { round 1: } \$ M 3, \\
\text { round 2: } \$ M 11,4 \\
\text { priv. }\end{array}$ & $\begin{array}{l}\text { Sabse Tech. (NA, } \\
\text { founded in 2008), } \\
\text { Sept 29, } 2009\end{array}$ \\
\hline $\begin{array}{l}\text { Goal } \\
\text { Semiconductor } \\
\text { Inc. }\end{array}$ & $\begin{array}{l}\text { Fabless semiconductor } \\
\text { company supplying } \\
\text { integrated circuits for } \\
\text { sensor signal conditioning }\end{array}$ & $\begin{array}{l}13 \text { years, } \\
\text { Montréal }\end{array}$ & $\begin{array}{l}1 \text { round, } 3 \text { gov.: } \\
\text { \$M4.1 }\end{array}$ & $\begin{array}{l}\text { Ramtron Int. } \\
\text { (Nasdaq), \$M9 } \\
\text { (US\$M34), Aug 29, } \\
2005\end{array}$ \\
\hline $\begin{array}{l}\text { Haptic } \\
\text { Technologies } \\
\text { Inc. }\end{array}$ & $\begin{array}{l}\text { Developer of haptic } \\
\text { computer peripherals and } \\
\text { software technologies }\end{array}$ & $\begin{array}{l}4 \text { years, } \\
\text { Montréal }\end{array}$ & $\begin{array}{l}1 \text { round: \$M1.2, } 2 \\
\text { gov. }\end{array}$ & $\begin{array}{l}\text { Immersion Corp. } \\
\text { (Nasdaq), \$M10 } \\
\text { (US\$M58), Feb 26, } \\
2000\end{array}$ \\
\hline $\begin{array}{l}\text { Mycota } \\
\text { Biosciences Inc. }\end{array}$ & $\begin{array}{l}\text { Identification of } \\
\text { antifungal essential drug } \\
\text { targets and antimicrobial } \\
\text { functional genomics }\end{array}$ & $\begin{array}{l}9 \text { years, } \\
\text { Montréal }\end{array}$ & $\begin{array}{l}\text { round 1: } \$ M 2.5 \text {, } \\
\text { round 2: } \$ M 1.64 \text {, } \\
1 \text { gov. and } 3 \text { priv. }\end{array}$ & $\begin{array}{l}\text { Elitra, \$M30 } \\
\text { (US\$M23). Elitra } \\
\text { reinvests \$M10, Dec } \\
7,2000 .\end{array}$ \\
\hline Tomoye Corp. & $\begin{array}{l}\text { Editor of social } \\
\text { networking site based on } \\
\text { Microsoft Sharepoint }\end{array}$ & $\begin{array}{l}10 \text { years, } \\
\text { Gatineau }\end{array}$ & $\begin{array}{l}1 \text { round: \$M1.1, } 4 \\
\text { gov. }\end{array}$ & $\begin{array}{l}\text { Newgator Tech. } \\
\text { (NA, created in } \\
\text { 2004), Jan 20, } 2010\end{array}$ \\
\hline Traf-Park Inc. & $\begin{array}{l}\text { Automated parking } \\
\text { systems }\end{array}$ & $\begin{array}{l}14 \text { years, } \\
\text { Boucherville }\end{array}$ & $\begin{array}{l}1 \text { round: } \\
\$ M 0.96,1 \text { gov. et } \\
\text { priv. }\end{array}$ & $\begin{array}{l}\text { Subsidiary of Cubic } \\
\text { Corp. (Amex), \$M4 } \\
\text { (US\$M543), Sept 2, } \\
2004\end{array}$ \\
\hline $\begin{array}{l}\text { Micro Thermo } \\
\text { Inc. }\end{array}$ & $\begin{array}{l}\text { Energy management and } \\
\text { environmental control } \\
\text { systems for supermarkets }\end{array}$ & 15 years, Laval & $\begin{array}{l}1 \text { round: \$M3.5, } 1 \\
\text { gov. }\end{array}$ & $\begin{array}{l}\text { Carrier Corp., } \\
\text { subsidiary of UTC } \\
\text { (NYSE), Aug 10, } \\
2001\end{array}$ \\
\hline $\begin{array}{l}\text { GEOCOMtms } \\
\text { Inc. }\end{array}$ & $\begin{array}{l}\text { Fleet management } \\
\text { software for local and } \\
\text { short-haul pickup and } \\
\text { delivery operations }\end{array}$ & 8 years, Québec & $\begin{array}{l}7 \text { rounds: } \\
\text { \$M20.29, } 3 \text { gov. } \\
\text { et } 3 \text { priv. } \\
\text { including } 1 \text { US }\end{array}$ & $\begin{array}{l}\text { Redprairie (Rev. } \\
\text { US\$M253), Feb 22, } \\
2007\end{array}$ \\
\hline
\end{tabular}


Table 2, Continued

\begin{tabular}{|c|c|c|c|c|}
\hline Company name & Product or service & Age and location & Financing rounds & $\begin{array}{l}\text { US acquirer and } \\
\text { acquisition date }\end{array}$ \\
\hline $\begin{array}{l}\text { Polyplan Tech. } \\
\text { Inc. }\end{array}$ & $\begin{array}{l}\text { Software linking } \\
\text { manufacturing process } \\
\text { management and product } \\
\text { development }\end{array}$ & $\begin{array}{l}5 \text { years, } \\
\text { Montréal }\end{array}$ & $\begin{array}{l}3 \text { rounds: } \$ \text { M8.95, } \\
2 \text { gov. , } 2 \text { priv. } \\
\text { and others not } \\
\text { identified }\end{array}$ & $\begin{array}{l}\text { Parametric Tech. } \\
\text { (NASDAQ, PTC) } \\
\text { (US\$M676), June 5, } \\
2005\end{array}$ \\
\hline $\begin{array}{l}\text { Colubris } \\
\text { Network Inc. }\end{array}$ & $\begin{array}{l}\text { Wireless local area } \\
\text { network solutions for } \\
\text { enterprises and service } \\
\text { providers }\end{array}$ & 9 years, Laval & $\begin{array}{l}5 \text { rounds: } \$ \text { M66, } 1 \\
\text { gov., } 5 \text { priv. US } \\
\text { and others not } \\
\text { identified. }\end{array}$ & $\begin{array}{l}\text { Subsidiary of HP } \\
\text { (NYSE), Aug 25, } \\
2008\end{array}$ \\
\hline Cilys Inc. & $\begin{array}{l}\text { Wireless optimization } \\
\text { solution for packet- } \\
\text { switched wireless } \\
\text { networks }\end{array}$ & $\begin{array}{l}5 \text { years, Trois } \\
\text { Rivières }\end{array}$ & $\begin{array}{l}3 \text { rounds: } \$ M 7.6 \text {, } \\
5 \text { gov. and priv. }\end{array}$ & $\begin{array}{l}\text { Openwave } \\
\text { (NASDAQ),\$M12 } \\
\text { (US\$M477), Jan 31, } \\
2005\end{array}$ \\
\hline $\begin{array}{l}\text { Terrascale } \\
\text { Technologies } \\
\text { Inc. }\end{array}$ & $\begin{array}{l}\text { Software dedicated to } \\
\text { storage solutions for } \\
\text { enterprise cluster and grid } \\
\text { applications. }\end{array}$ & $\begin{array}{l}4 \text { years, } \\
\text { Montréal }\end{array}$ & $\begin{array}{l}1 \text { round, \$M2.7, } 2 \\
\text { gov. }\end{array}$ & $\begin{array}{l}\text { Rackable Systems } \\
\text { Inc., US\$M38 } \\
\text { (US\$M176), Aug 29, } \\
2006\end{array}$ \\
\hline $\begin{array}{l}\text { Timespring } \\
\text { Software Corp. }\end{array}$ & $\begin{array}{l}\text { Continuous data } \\
\text { protection software }\end{array}$ & $\begin{array}{l}13 \text { years, } \\
\text { Montréal }\end{array}$ & $\begin{array}{l}2 \text { rounds, } \\
\$ \mathrm{M} 19.75,2 \text { gov., } \\
2 \text { priv. and others } \\
\text { not identified }\end{array}$ & $\begin{array}{l}\text { Double-Take } \\
\text { software } \\
\text { (NASDAQ), } \\
\text { US\$M8.3 } \\
\text { (US\$M77), Dec 24, } \\
2007\end{array}$ \\
\hline
\end{tabular}


Table 3 Foreign trade sales' motivation analysis

\begin{tabular}{|c|c|c|c|c|c|c|}
\hline Name & $\begin{array}{l}\text { Same } \\
\text { sector } \\
\left(\mathrm{O}_{1.1}\right)\end{array}$ & $\begin{array}{l}\text { Explicit market } \\
\text { consideration } \\
\left(\mathrm{O}_{1.2}\right)\end{array}$ & $\begin{array}{l}\text { Complementarity and synergy } \\
\text { effects } \\
\left(\mathrm{O}_{1.3}\right)\end{array}$ & $\begin{array}{l}\text { No Recent } \\
\text { local VC } \\
\left(\mathrm{O}_{2.1}\right)\end{array}$ & $\begin{array}{l}\text { Foreign } \\
\text { VC } \\
\left(\mathrm{O}_{2.2}\right)\end{array}$ & $\begin{array}{l}\text { Financial } \\
\text { constraints } \\
\left(\mathrm{O}_{2.3}\right)\end{array}$ \\
\hline $\begin{array}{l}\text { Pyderion Contact } \\
\text { Techno. }\end{array}$ & Yes & $\begin{array}{l}\text { To access a } \\
\text { larger market }\end{array}$ & $\begin{array}{l}\text { To enhance Intecom's offerings to } \\
\text { the contact centre market }\end{array}$ & $\begin{array}{l}\text { No (10 } \\
\text { months) }\end{array}$ & No & No \\
\hline Movibox Corp. & Yes & $\begin{array}{l}\text { To access a large } \\
\text { market }\end{array}$ & Complementary technologies & $\begin{array}{l}\text { No }(2 \\
\text { years })\end{array}$ & No & No \\
\hline $\begin{array}{l}\text { Goal } \\
\text { Semiconductor }\end{array}$ & Yes & No & $\begin{array}{l}\text { Products are highly } \\
\text { complementary, to accelerate } \\
\text { product development and delivery }\end{array}$ & $\begin{array}{l}\text { No }(1.5 \\
\text { year })\end{array}$ & No & No \\
\hline Haptic Techno. & Yes & No & $\begin{array}{l}\text { Large synergies of R\&D efforts, } \\
\text { and complementary technologies }\end{array}$ & $\begin{array}{l}\text { No }(7 \\
\text { months) }\end{array}$ & No & No \\
\hline $\begin{array}{l}\text { Mycota } \\
\text { Biosciences }\end{array}$ & Yes & No & $\begin{array}{l}\text { Very complementary expertise, } \\
\text { gene discovery and drug screening } \\
\text { technologies }\end{array}$ & $\begin{array}{l}\text { No }(6 \\
\text { months) }\end{array}$ & No & No \\
\hline Tomoye Corp. & Yes & No & $\begin{array}{l}\text { Products and customers are very } \\
\text { complementary }\end{array}$ & $\begin{array}{l}\text { Yes }(5 \\
\text { years) }\end{array}$ & No & No \\
\hline Traf-Park Inc. & Yes & $\begin{array}{l}\text { To access new } \\
\text { markets and } \\
\text { services }\end{array}$ & $\begin{array}{l}\text { Complementary products, to adapt } \\
\text { Cubic’s smart-card to automated } \\
\text { parking systems }\end{array}$ & $\begin{array}{l}\text { Yes }(4 \\
\text { years) }\end{array}$ & No & No \\
\hline $\begin{array}{l}\text { Micro-Thermo } \\
\text { Techno. }\end{array}$ & Yes & $\begin{array}{l}\text { To access a } \\
\text { worldwide market }\end{array}$ & $\begin{array}{l}\text { Complementary products; to } \\
\text { provide a full range of products } \\
\text { and services }\end{array}$ & $\begin{array}{l}\text { No }(1.8 \\
\text { years })\end{array}$ & No & No \\
\hline Geocomtms & Yes & No & $\begin{array}{l}\text { The acquirer already distributed } \\
\text { the products of Geocomtms and is } \\
\text { rapidly growing through } \\
\text { acquisitions }\end{array}$ & $\begin{array}{l}\text { No }(1.8 \\
\text { years })\end{array}$ & Yes & No \\
\hline Polyplan techno. & Yes & $\begin{array}{l}\text { To access the } \\
\text { market }\end{array}$ & $\begin{array}{l}\text { PTC wants to completely integrate } \\
\text { Polyplan's solution that PTC is } \\
\text { already distributing }\end{array}$ & $\begin{array}{l}\text { Yes }(2.2 \\
\text { years })\end{array}$ & No & No \\
\hline Colubris Network & Yes & $\begin{array}{l}\text { Access to market } \\
\text { using HP's } \\
\text { channel network. }\end{array}$ & $\begin{array}{l}\text { HP completely integrated } \\
\text { Colubris’s line into its portfolio. }\end{array}$ & $\begin{array}{l}\text { No }(1.9 \\
\text { years })\end{array}$ & Yes & No \\
\hline Cilys & Yes & Access to market & Products are complementary & $\begin{array}{l}\text { No }(1 \\
\text { month) }\end{array}$ & No & No \\
\hline $\begin{array}{l}\text { Terrascale } \\
\text { Techno. }\end{array}$ & Yes & No & $\begin{array}{l}\text { Product are complementary: } \\
\text { Rackable sells servers while } \\
\text { Terrascale sells storage to rapidly } \\
\text { feed servers with data }\end{array}$ & $\begin{array}{l}\text { Yes }(2.4 \\
\text { years })\end{array}$ & No & No \\
\hline $\begin{array}{l}\text { Timespring } \\
\text { software Corp. }\end{array}$ & Yes & No & $\begin{array}{l}\text { Products and expertise are } \\
\text { complementary }\end{array}$ & $\begin{array}{l}\text { Yes }(3 \\
\text { years) }\end{array}$ & No & No \\
\hline
\end{tabular}


Table 4 Consequences of the acquisition. $\mathrm{O}_{3.1}$ means the $\mathrm{R} \& \mathrm{D}$ activity of acquired NTBF does not increase following the acquisition, $\mathrm{O}_{3.2}$ means the acquired Canadian NTBF become truncated companies, $\mathrm{O}_{3.3}$ means there is little evidence of recycling activities. IC (rev.) means Industry Canada (revenues).

\begin{tabular}{|c|c|c|c|c|}
\hline Name & Fate of the company & $\begin{array}{l}\text { Local } \\
\text { impact? }\end{array}$ & Fate of the founders & $\begin{array}{l}\text { Little } \\
\text { evidence of } \\
\text { recycling } \\
\text { effect? }\end{array}$ \\
\hline $\begin{array}{l}\text { Pyderion Contact } \\
\text { Techno. }\end{array}$ & $\begin{array}{l}\text { Intecom bought by } \\
\text { Aastra (Ontario). No } \\
\text { longer active in Canada. }\end{array}$ & $\begin{array}{l}\mathrm{O}_{3.1} \text { yes } \\
\mathrm{O}_{3.2} \text { yes }\end{array}$ & $\begin{array}{l}\text { The CEO became CEO of a start-up in Ottawa } \\
\text { until sold to Los Angeles-based company and } \\
\text { then became managing partner of a venture } \\
\text { capital firm in Montréal. }\end{array}$ & $\mathrm{O}_{3.3}$ yes \\
\hline Movibox Corp. & $\begin{array}{l}\text { No longer active in } \\
\text { Canada. }\end{array}$ & $\begin{array}{l}\mathrm{O}_{3.1} \text { yes } \\
\mathrm{O}_{3.2} \text { yes }\end{array}$ & $\begin{array}{l}\text { The founder and CTO stayed } 9 \text { months with } \\
\text { Movibox's acquirer and then became the CEO } \\
\text { of a small high tech company near Montreal. }\end{array}$ & $\mathrm{O}_{3.3}$ yes \\
\hline $\begin{array}{l}\text { Goal } \\
\text { Semiconductor }\end{array}$ & $\begin{array}{l}\text { No longer active at the } \\
\text { initial location. Acquirer } \\
\text { still active in Canada. }\end{array}$ & $\begin{array}{l}\mathrm{O}_{3.1} \text { yes } \\
\mathrm{O}_{3.2} \text { yes }\end{array}$ & $\begin{array}{l}\text { The founder and CEO founded another high } \\
\text { tech company in Ottawa, then became CTO of } \\
\text { a small high tech company in Ontario and is } \\
\text { now director of a local development centre in } \\
\text { Sherbrooke. }\end{array}$ & $\mathrm{O}_{3.3}$ yes \\
\hline Haptic Techno. & $\begin{array}{l}\text { Still operates in } \\
\text { Montréal (16 } \\
\text { employees) in R\&D } \\
\text { activities, rev. \$M1.5 }\end{array}$ & $\begin{array}{l}\mathrm{O}_{3.1} \text { no } \\
\mathrm{O}_{3.2} \text { yes }\end{array}$ & $\begin{array}{l}\text { The co-founder and CTO became the CTO of } \\
\text { the Haptic's acquirer, and is now President and } \\
\text { CEO at a San-Francisco-based high tech } \\
\text { company founded in 2006. The co-founder and } \\
\text { CEO stayed three years with the acquirer, } \\
\text { became CEO or VP in four Montréal-based } \\
\text { ITC start-ups. }\end{array}$ & $\mathrm{O}_{3.3}$ yes \\
\hline $\begin{array}{l}\text { Mycota } \\
\text { Biosciences }\end{array}$ & $\begin{array}{l}\text { Acquired by Merck } \\
\text { Frost Canada. No longer } \\
\text { active in Canada. }\end{array}$ & $\begin{array}{l}\mathrm{O}_{3.1} \text { yes } \\
\mathrm{O}_{3.2} \text { yes }\end{array}$ & $\begin{array}{l}\text { One co-founder is a professor. The other one } \\
\text { has been VP or CEO in five small biotech } \\
\text { companies, and is portfolio manager of a local } \\
\text { VC firm. }\end{array}$ & $\mathrm{O}_{3.3}$ yes \\
\hline Tomoye Corp. & $\begin{array}{l}\text { Still at initial location } \\
\text { (Québec, } 25 \\
\text { employees), R\&D } \\
\text { activities, rev. \$M2.4 }\end{array}$ & $\begin{array}{l}\mathrm{O}_{3.1} \text { no } \\
\mathrm{O}_{3.2} \text { yes }\end{array}$ & $\begin{array}{l}\text { The co-founder and CEO stayed three years } \\
\text { with the acquirer. He then co-founded and } \\
\text { became CEO of a start-up in Ottawa. The co- } \\
\text { founder and CTO became an executive director } \\
\text { of a non-profit environmental organisation in } \\
\text { Ottawa. }\end{array}$ & $\mathrm{O}_{3.3}$ yes \\
\hline Traf-Park Inc. & $\begin{array}{l}\text { No longer active at } \\
\text { initial location. Buyer } \\
\text { operates a sales office } \\
\text { (10 employees). }\end{array}$ & $\begin{array}{l}\mathrm{O}_{3.1} \text { yes } \\
\mathrm{O}_{3.2} \text { yes }\end{array}$ & $\begin{array}{l}\text { The founder is heading a sales office of the } \\
\text { company in Montréal. }\end{array}$ & $\mathrm{O}_{3.3}$ yes \\
\hline $\begin{array}{l}\text { Micro-Thermo } \\
\text { Techno. }\end{array}$ & $\begin{array}{l}\text { Still in Laval as an R\&D } \\
\text { division, } 57 \text { employees, } \\
\text { rev. \$M5 to } 10 \text { (IC). }\end{array}$ & $\begin{array}{l}\mathrm{O}_{3.1} \text { no } \\
\mathrm{O}_{3.2} \text { yes }\end{array}$ & $\begin{array}{l}\text { The founder and president is still a business } \\
\text { unit manager at Microthermo (a division of } \\
\text { Parker Hannifin Canada). }\end{array}$ & $\mathrm{O}_{3.3}$ yes \\
\hline
\end{tabular}




\begin{tabular}{|c|c|c|c|c|}
\hline Name & Fate of the company & $\begin{array}{l}\text { Local } \\
\text { impact? }\end{array}$ & Fate of the founders & $\begin{array}{l}\text { Little } \\
\text { evidence of } \\
\text { recycling } \\
\text { effect? }\end{array}$ \\
\hline Geocomtms & $\begin{array}{l}\text { No longer exists at } \\
\text { initial location. The } \\
\text { buyer operates an office } \\
\text { (Montréal), } 25 \\
\text { employees. }\end{array}$ & $\begin{array}{l}\mathrm{O}_{3.1} \text { yes } \\
\mathrm{O}_{3.2} \text { yes }\end{array}$ & $\begin{array}{l}\text { The founder and CEO (serial entrepreneur) } \\
\text { became the president of a high tech Québec } \\
\text { two-year old company. He is also behind the } \\
\text { creation and investment of Berclain Group } \\
\text { (sold to German IT Baan in 1996) and Taleo } \\
\text { (sold to Oracle in 2012). }\end{array}$ & $\mathrm{O}_{3.3}$ no \\
\hline Polyplan techno. & $\begin{array}{l}\text { A small office still } \\
\text { exists in Montréal (13 } \\
\text { employees) }\end{array}$ & $\begin{array}{l}\mathrm{O}_{3.1} \text { yes } \\
\mathrm{O}_{3.2} \text { yes }\end{array}$ & $\begin{array}{l}\text { Founder is professor and CEO of a non-profit } \\
\text { organisation. }\end{array}$ & $\mathrm{O}_{3.3}$ yes \\
\hline Colubris Network & $\begin{array}{l}\text { Staff integrated to HP, } \\
\text { still in Montréal, R\&D } \\
\text { centre. }\end{array}$ & $\begin{array}{l}\mathrm{O}_{3.1} \text { no } \\
\mathrm{O}_{3.2} \text { yes }\end{array}$ & $\begin{array}{l}\text { Founder became a consultant in the Montréal } \\
\text { area and is President of Californian a telecom } \\
\text { high tech company founded in } 1970 .\end{array}$ & $\mathrm{O}_{3.3}$ yes \\
\hline Cilys & $\begin{array}{l}\text { No longer exists in } \\
\text { Canada. }\end{array}$ & $\begin{array}{l}\mathrm{O}_{3.1} \text { yes } \\
\mathrm{O}_{3.2} \text { yes }\end{array}$ & $\begin{array}{l}\text { The first co-founder (serial entrepreneur) is } \\
\text { CEO of a company founded in } 1999 \text { in } \\
\text { Montréal. In 2007, with the second Cilys' co- } \\
\text { founder and CFO, he co-founded another } \\
\text { Montréal-based start-up, then sold to a US } \\
\text { company. The third Cilys' co-founder is CTO } \\
\text { in a New-York firm. }\end{array}$ & $\mathrm{O}_{3.3}$ no \\
\hline Terrascale Techno. & $\begin{array}{l}\text { No longer exists in } \\
\text { Canada. Integration } \\
\text { failed. Sold } 2 \text { years later } \\
\text { to another US firm. }\end{array}$ & $\begin{array}{l}\mathrm{O}_{3.1} \text { yes } \\
\mathrm{O}_{3.2} \text { yes }\end{array}$ & $\begin{array}{l}\text { The founder (a seasoned technology } \\
\text { entrepreneur and investor) became the CEO } \\
\text { of a small Floridian technology company } \\
\text { founded in } 2008 \text {. }\end{array}$ & $\mathrm{O}_{3.3}$ yes \\
\hline $\begin{array}{l}\text { Timespring software } \\
\text { Corp. }\end{array}$ & $\begin{array}{l}\text { Buyer acquired by } \\
\text { Vision Solutions } \\
\text { (2010). Small office in } \\
\text { Montréal (10 } \\
\text { employees). }\end{array}$ & $\begin{array}{l}\mathrm{O}_{3.1} \text { yes } \\
\mathrm{O}_{3.2} \text { yes }\end{array}$ & $\begin{array}{l}\text { The CTO and CEO became the executive } \\
\text { chairman and CTO of an employee-owned } \\
\text { start-up in California }\end{array}$ & $\mathrm{O}_{3.3}$ yes \\
\hline
\end{tabular}


Appendix 1 Summary of the most successful exits by the Canadian VC Industry, based on the CVCA's Deal of the Year Award, 2005-2012. Gov. means Government-sponsored funds.

In 2012, BDC Venture Capital (Gov.) and New Brunswick Investment (Gov.) won the prize for their investment in Q1 Labs, a global provider of next-generation security intelligence products. In October, 2011, Q1 Labs was sold to IBM. The investment generated an internal rate of return of $32.8 \%$.

In 2011, Summerhill Venture Partners, Brightspark Ventures and BDC Venture Capital (Gov.) won the prize for their investment in Radian6 Technologies Inc. a social media monitoring company founded in 2006, acquired by Salesforce.com (San Francisco) in March 2011 for US\$326 million.

The 2010 Deal of the Year was given to Covington for their investment in SXC Health Solutions Inc., a leading provider of pharmacy benefit management services and healthcare information technology solutions. This firm listed on the TSX and NASDAQ in 2006, under the name Catamaran Corp., moved its head office to the US. Covington sold its shares in 2010, July. The stock was mainly (79.9\%) traded in the US in 2012. According to the 2011 10K (p.70), the Canadian operations account for less than 1\% of the firm's revenues from 2009 to 2011.

In 2009, three Gov. won the award for their joint investment in ViroChem Pharma, Inc., acquired in 2009 by Vertex Pharmaceuticals (Canada) Inc., a subsidiary of Vertex Pharmaceuticals Inc., a US firm listed on NASDAQ.

In 2008, Covington Capital won an award for its success with PlateSpin, a Toronto-based firm that provides a suite of solutions to help enterprises to manage their use of server virtualisation in the data centre, acquired by Novell in 2008, March, for US\$205 million.

In 2007, GrowthWorks Canadian Fund specialised in the management and growth of regionally based VC funds, including several Gov. funds. It won an award for its investment in Galleon Energy Inc., a rapid growing petroleum firm that listed on the TSX Venture exchange in 2003 and graduated to the main board in 2005.

In 2006, BC Advantage Funds (Gov.) won the award for its investment in Aspreva Pharma, specialised in the treatment of less common diseases. After an IPO in 2005 and a NASDAQ listing, Aspreva was acquired by Galenica Group (Swiss) in 2007 and integrated in its subsidiary Vifor Pharma. The number of employees was about 150 at this time, and was estimated at 36 in 2012.

Propulsion Ventures won the 2005 prize for its investment in Airborne, a designer and publisher of mobile entertainment applications and services, acquired by Cyberd co., a Japanese mobile media company, in a transaction valued at approximately US\$90 million 